\title{
Ocular dryness assessment in Saudi employees working indoors and outdoors
}

This article was published in the following Dove Press journal:

Clinical Optometry

\author{
Raied Fagehi' \\ Hani Ghazal ${ }^{2}$ \\ Saad Alrabiah ${ }^{2}$ \\ Ali Abusharha' \\ Saud Alanazi' \\ Ali Alsaqr ${ }^{1}$ \\ Ali Masmali ${ }^{3}$
}

'Department of Optometry, College of Applied Medical Sciences, King Saud University, Riyadh, Saudi Arabia; ${ }^{2}$ Ophthalmology Department, King Fahad Medical City, Riyadh, Saudi Arabia; ${ }^{3}$ Cornea Research Chair, Department of Optometry, College of Applied Medical Sciences, King Saud University, Riyadh, Saudi Arabia
Correspondence: Raied Fagehi

Department of Optometry, College of Applied Medical Sciences, King Saud University, PO Box 93635, Riyadh II683, Saudi Arabia

Tel +9665505I 56I8

Email Rfagehi@ksu.edu.sa
Objective: To investigate dry eye disease in Saudi employees working in indoor and outdoor environments.

Methods: A single-center randomized controlled study was carried out in an optometry clinic, to assess the ocular dryness of 24 male employees ( 12 indoor and 12 outdoor employees, mean age $36.4 \pm 2.5$ years). The Ocular Surface Disease Index questionnaire was used to assess ocular dryness. Tear film assessment was carried out using phenol red thread (PRT), tear film osmolarity test, and fluorescein tears breakup time (FTBUT) with slit-lamp biomicroscopy.

Results: Both indoor and outdoor employees showed mild-to-moderate ocular dryness. A significant difference $(P=0.004)$ was found for the tear quality test (FTBUT) between the indoor $(8.58 \pm 4.8)$ and outdoor $(5.54 \pm 1.3)$ employees. However, no significant differences for the tear quantity tests (tear osmolarity and PRT) between the indoor and outdoor employees were observed.

Conclusion: Dry eye cases were detected in both groups. This might be due to the hot dry environment in Riyadh and the use of air conditioners commonly used indoors. A significant difference was observed for the tear film stability, which might be due to the effect of environment and/or visual display unit use.

Keywords: tear film, ocular dryness, tear osmolarity, environment

\section{Introduction}

Dry eye disease is one of the conditions most seen by eye practitioners, and this is a reflection of the percent of patients who suffer from dry eye symptoms. ${ }^{1,2}$ Dry eye disease is defined as "a multifactorial disorder of the tears and ocular surface that results in discomfort, visual disturbance, and tear film instability with potential damage to the ocular surface. ${ }^{3 \text { " }}$ Reports also suggested that a high tear osmolarity and inflammation of the ocular surface might be observed in dry eye cases. ${ }^{3}$

Dry eye disease can be classified as episodic or chronic. Episodic dry eye occurs when the environment or visual tasks with low blink rate overcome the stability of the tear and produce symptomatic dry eye. Dry eye chronic cases, developed in similar environmental condition, continue with possible harm to the ocular surface. ${ }^{4}$

Environmental dry eye disease (EDED) is a case that qualifies the dry eye disease definition. ${ }^{3}$ Environmental contact, such as pollutants and adverse effects of climate, is the most relevant causal factor. ${ }^{5}$ People suffer from EDED because of exposure to a variety of environmental conditions. ${ }^{6}$ The exposure to outdoor and indoor environmental 
influences can result in similar EDED clinical signs; however, the diagnosis and treatment are different for each case.

The indoor environment conditions (such as offices, health care facilities, subway stations, and other employment areas) have a variation in humidity and airflow and a longtime presence in front of computer or video display units. Outdoors are areas with extreme temperatures, gases, and/or air suspended particles in desiccating wind. These definitions help in research, clinical, and therapeutic purposes. ${ }^{5}$

The effect of the environment on the tear film has been investigated by several studies. ${ }^{7-12}$ Currently, a large number of people are exposed to adverse environments or artificial environments. Maruyama et al mentioned that as temperature rises and relative humidity $(\mathrm{RH})$ reduces, the tear film becomes thinner, tear breakup time reduces, and dryness increases. $^{13}$

There are a number of tear film tests clinically available to diagnose dry eye, such as the tear stability (quality) tests (i.e., tear breakup time and tear thinning rate), ${ }^{14}$ tear quantity tests (such as Schirmer test ${ }^{15}$ and phenol red thread ${ }^{16}$ [PRT] test), and tear osmolarity test. ${ }^{14,17}$

The purpose of this study was to assess the ocular dryness in indoor and outdoor employees in Riyadh, Saudi Arabia, where the outdoor weather is hot and dry, and the indoor environment is usually controlled using air conditioners.

This study compared the tear film physiology, in a real-life situation, between external (hot environment) and internal (air-conditioned rooms) environments.

\section{Materials and methods}

Twenty-four subjects (12 indoor [i.e., optometrist, nursing staff] and 12 outdoor employees [i.e., gates security; men, age $36.4 \pm 2.5$ years]) were recruited to take part in this cross-sectional study. The inclusion criteria were $>23$ years old, employee, non-contact lens or sunglasses wearers, no history of ocular or systemic diseases, and no ocular or systemic treatment used during or prior to participation in this study. This study was approved by the Research Ethics Committee, College of Applied Medical Sciences, King Saud University, and subjects were treated according to the tenets of the Declaration of Helsinki. ${ }^{18}$ All subjects gave written informed consent and no payment or inducement was offered to subjects to volunteer to take part.

All participants from each group were asked to come to a clinic for one visit, after a period between 4 and 6 hours of exposure to either indoor or outdoor environment. A series of tear film tests were performed. These included (from minimum invasive to invasive tests) PRT tests, tear osmolarity, and fluorescein tear breakup time (FTBUT) using slit-lamp biomicroscopy. Additionally, the Ocular Surface Disease Index (OSDI) was used to evaluate the ocular dryness subjectively. The subjects showing OSDI score $\leq 15$ were included in this study to avoid the effect of ocular dryness symptoms on the study. Several studies have used the OSDI questionnaire with different cutoff values. The OSDI range for dry eye in the literature is $10-35 .^{8,17,21}$ Abusharha and Pearce (2012) used 10 as the upper limit of the normal range in their study, ${ }^{8}$ whereas Messmer et $\mathrm{al}^{19}$ used an OSDI questionnaire score of 15 as the upper limit of the normal range.

\section{Ocular Surface Disease Index}

Before performing the objective tests to evaluate the physiology of the tear film, the OSDI questionnaire was completed by each subject to evaluate the subjective ocular dryness. The OSDI questionnaire was designed by a research group at Allergan Inc., Irvine, CA, USA, ${ }^{20}$ and consists of 12 questions in three parts. The first part contains five questions to evaluate eye symptoms, the next four questions to evaluate the visual function in different conditions, and the last three questions to evaluate dry eye related to environmental conditions. $^{21}$ The normal OSDI value is between 10.4 and 11.4 and it depends on the sum of the scores and the number of questions answered. ${ }^{22}$

\section{Phenol red thread}

The PRT (Zone Quick, Showa Yakuhin Kako, Japan) cotton strip was hooked over the inferior lid on the temporal side of the eye. The wet lengths were measured after $15 \mathrm{~s}$. One PRT measurement only was taken per subject, since according to Tomlinson et al, multiple PRT measurements at one session showed no significant difference. ${ }^{16}$

\section{Tear osmolarity}

OcuSense TearLab Osmometer (OcuSense Inc., San Diego, CA, USA) measures the osmolarity of tears by means of a proprietary impedance spectroscopy technique. ${ }^{23}$ This technique offers quick and accurate measurement of osmolarity from one measurement of a very small sample of fluid $(<0.2 \mu \mathrm{L}) .{ }^{24}$ The normal tear osmolarity is between 290 and $304 \mathrm{mOsm} / \mathrm{L}$.

\section{Fluorescein tear breakup time}

Indirect tear film stability can be assessed with FTBUT, with $<10$ s stability of tear film indicating dry eye. ${ }^{25}$ A fluorescein strip was applied to the inferior palpebral conjunctiva. Subjects were asked to blink completely and gently three 
times. The slit-lamp cobalt blue filter was used to observe the stability of the tear film. The presence of the first precorneal spot was recorded as the breakup time in seconds.

\section{Statistical tests}

All the data were analyzed for normality using KolmogorovSmirnov test (IBM SPSS Version 22 [IBM Corporation, Armonk, NY, USA]). For normally distributed data, the independent-sample $t$-test was applied to compare tear physiology between the subjects.

\section{Results}

The results (Table 1) showed that the FTBUT of the outdoor employee $(5.54 \pm 1.3 \mathrm{sec})$ was significantly less $(P=0.004)$ compared to FTBUT of the indoor employee $(8.58 \pm 4.8)$ (Figure 1).

Table I The mean values of tear film tests between indoor and outdoor employees

\begin{tabular}{lll}
\hline & Mean \pm SD & \\
\cline { 2 - 3 } & Indoor employees & Outdoor employees \\
\hline $\begin{array}{l}\text { Tear osmolarity, } \\
\text { mOsmol/L }\end{array}$ & $309.25 \pm 11.8$ & $308.35 \pm 10.6$ \\
FTBUT, $\mathrm{s}$ & $8.58 \pm 4.8$ & $5.54 \pm 1.3$ \\
PRT, mm & $21.25 \pm 7.2$ & $24.72 \pm 6.6$ \\
\hline
\end{tabular}

Abbreviations: FTBUT, fluorescein tear breakup time; PRT, phenol red thread.
In contrast, the tear osmolarity of the indoor employee was $309.25 \pm 11.8$, whereas for the outdoor employee it was $308.35 \pm 10.6 \mathrm{mOsm} / \mathrm{L}$. However, the tear osmolarity difference between the groups was not significant $(P=0.61$; Figure $2)$. Also for the PRT, there was no significant difference $(P=0.94)$ between the indoor $(21.25 \pm 7.2 \mathrm{~mm})$ and outdoor employees (24.72 \pm 6.6 ; Figure 3).

\section{Discussion}

This study investigates the effect of two different environmental situations, indoor and outdoor, on ocular dryness. The study showed that the scores of the dryness assessment tests of the tear film are higher in indoor employees compared to outdoor employees for the tear osmolarity and PRT results.

The FTBUT was 5.54 and $8.58 \mathrm{~s}$ in outdoor and indoor employees, respectively. The tear quality test showed a significant difference between the two groups. This might be due to the high sensitivity of tear film stability in an adverse environment. The meibomian glands also play a vital role in tear stability as the lipid layer of the tears derives primarily from these glands. The lipid layer is responsible for maintaining tear film stability by reducing tear evaporation of the underlying aqueous layer. ${ }^{26}$

A significant correlation between ambient temperature and tear breakup time was reported by Abusharha et al. ${ }^{7}$ In

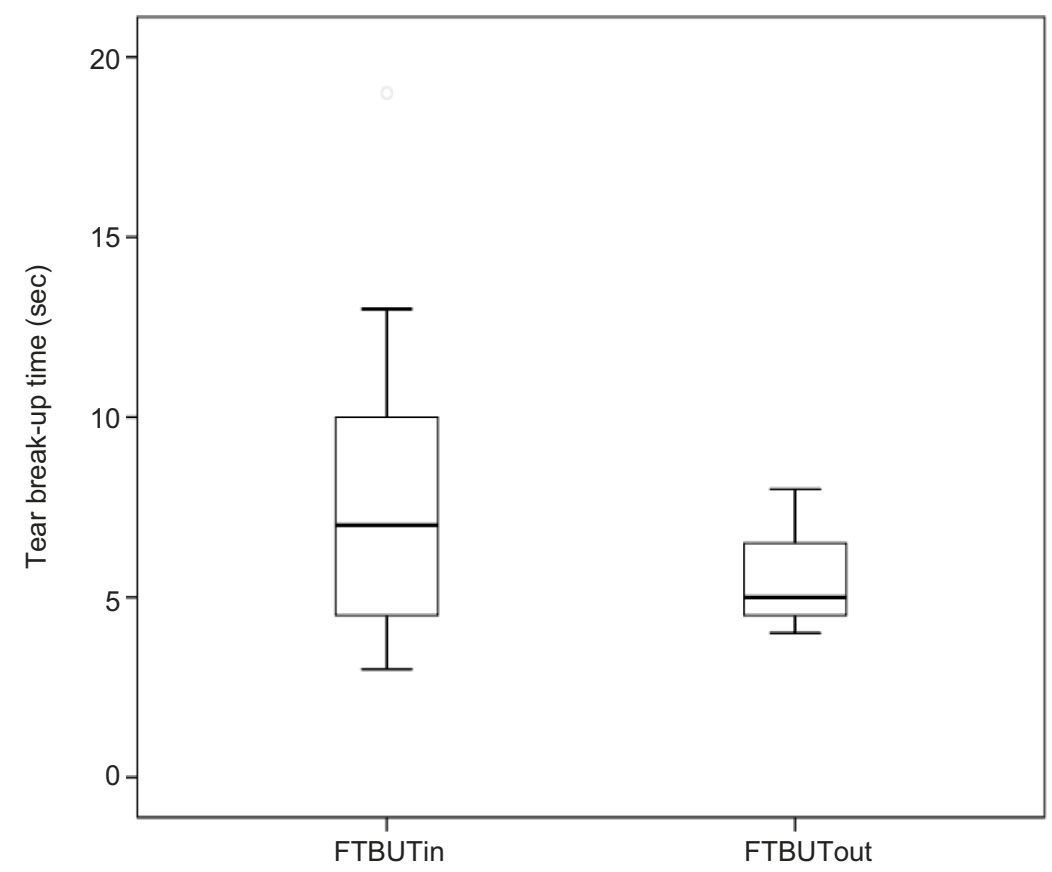

Figure I Box plots showing the difference in fluorescein tear breakup time between indoor (FTBUTin) and outdoor (FTBUTout) employees. 


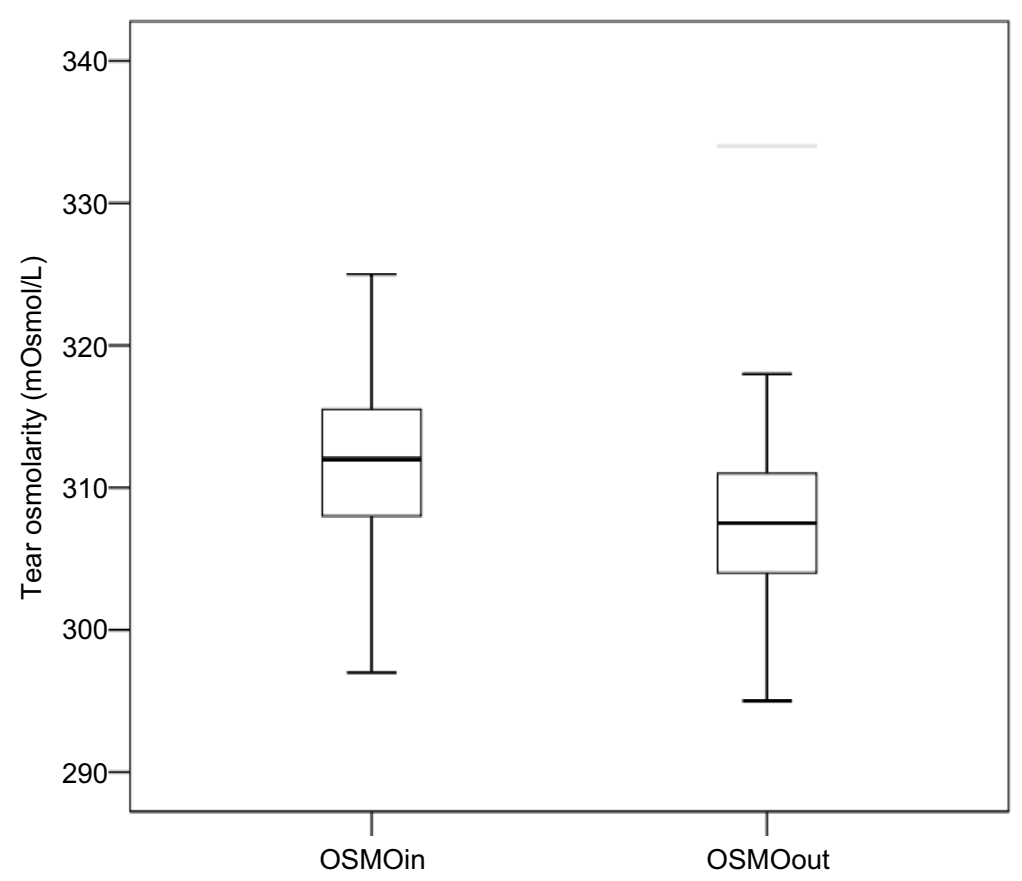

Figure 2 Box plots showing the difference in tear osmolarity between indoor (OSMOin) and outdoor (OSMOout) employees.

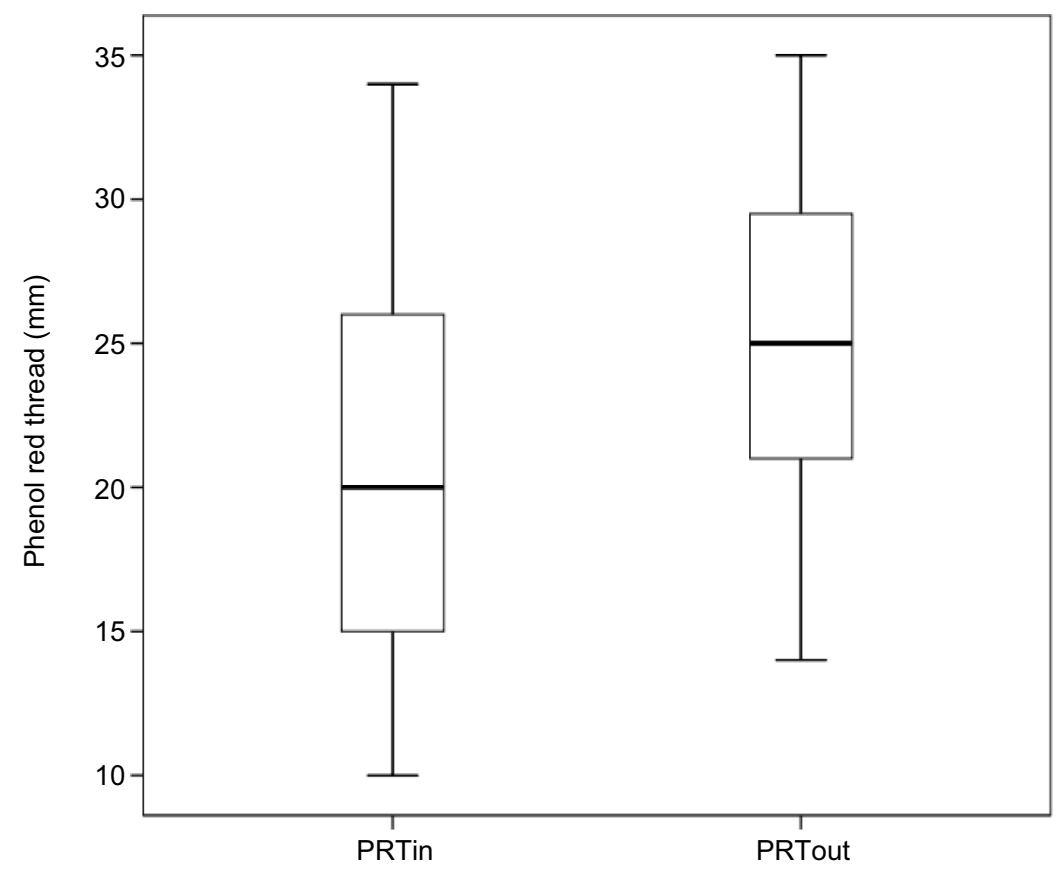

Figure 3 Box plots showing the difference in phenol red thread test results between indoor (PRTin) and outdoor (PRTout) employees.

addition, Wolkoff reported that thinning of the outer lipid layer of the precorneal tear film during a working day resulted in a lower breakup time. ${ }^{27}$

The tear osmolarity was $309.25 \mathrm{mOsmol} / \mathrm{L}$ for the indoor subjects and $308.35 \mathrm{mOsmol} / \mathrm{L}$ for the outdoor subjects.
These values are higher than the normal tear osmolarity values reported by the TearLab manufacturer or those reported in previous studies. ${ }^{17}$ Lemp $^{3}$ reported that a marker of dry eye condition is the increase in tear osmolarity. Both groups evaluated in this study were subjected to adverse 
environments and daily tasks, which were expected to cause a decrease in the tear thinning time and an increase in the tear evaporation rate, thus leading to high tear osmolarity. ${ }^{28}$ The tear production PRT wet length was found to be $24 \mathrm{~mm}$ in outdoor and $21 \mathrm{~mm}$ in indoor subjects. These values are very close to the normal PRT values. ${ }^{16,29}$ This might explain the mild-to-moderate, nonsevere, dry eye results observed in this study.

The comparison between the tear film test values obtained in this study and the normal tear film value from the literature showed that most of the tear film test results in both indoor and outdoor employees are not in the normal range. The normal tear osmolarity value is $290-304 \mathrm{mOsmol} / \mathrm{L}$. In 2013 , Masmali et a ${ }^{17}$ reported that the average tear osmolarity in Saudi Arabia (normal subjects) was $299.06 \mathrm{mOsmol} / \mathrm{L}$.

The normal FTBUT is $>10 \mathrm{~s}^{12}$ The low TBUT observed in the outdoor subjects might be a result of a high tear evaporation rate that can occur in the outdoor environment because of high temperatures and low humidity. ${ }^{27}$ In Riyadh, Saudi Arabia, during the summer time (when the data for this study were collected), the average temperature was $40^{\circ} \mathrm{C}$ and the average humidity was about $14 \%$ RH. Previous studies reported that an ambient environment could affect tear film condition. ${ }^{27,30}$ In 2013, Abusharha and Pearce reported that exposure to a desiccating environment adversely affects the tear film evaporation rate, lipid layer thickness, ocular comfort, tear film stability, and tear production. ${ }^{8}$

The slightly higher dry eye observed in indoor employees, in osmolarity and PRT, compared to outdoor employees might be a result of high tear evaporation rate that could have occurred in the indoor environment because of the presence of air conditioning, and/or the visual display unit use $\mathrm{e}^{31}$ and low humidity. ${ }^{7}$ The tear film condition in indoor employees also showed abnormality compared to normal tear film assessment values.

Previous reports suggested that a number of factors could affect the tear film in office employees. These factors include environmental ( $\mathrm{RH}$ and temperature), occupational (e.g., visual display unit work), and individual (e.g., gender, use of cosmetics, and medication) factors. Use of visual display units is a very common reason known to affect the blinking rate, which, therefore, affects the precorneal tear film stability, finally leading to tear film disruption. ${ }^{32}$ The indoor employees, especially those dealing with visual display units and spending long durations in air-conditioned rooms, have to consider increasing their blinking rate by using some reminder, and to assess their ocular surface regularly to avoid any dryness.

\section{Conclusion}

Although a small sample size was investigated in this study, both indoor and outdoor adverse environments can lead to ocular dryness. The outdoor environment might affect the tear stability more than the indoor environment. However, working in an indoor environment showed slightly higher signs of ocular dryness. Future work with a larger sample sizes and meibomian gland assessment might give extra information about the dry eye status in different environments.

\section{Acknowledgments}

The authors extend their appreciation to the College of Applied Medical Sciences Research Centre and Deanship of Scientific Research at King Saud University for funding this research.

\section{Disclosure}

The authors report no conflicts of interest in this work.

\section{References}

1. O'Brien PD, Collum LM. Dry eye: diagnosis and current treatment strategies. Curr Allergy Asthma Rep. 2004;4(4):314-319.

2. Gayton JL. Etiology, prevalence, and treatment of dry eye disease. Clin Ophthalmol. 2009;3:405-412.

3. Lemp MA. The definition and classification of dry eye disease: report of the definition and classification subcommittee of the International Dry Eye WorkShop (2007). Ocul Surf. 2007;5(2):75-92.

4. Foulks GN. Pharmacological management of dry eye in the elderly patient. Drugs Aging. 2008;25(2):105-118.

5. Alves, M, Novaes P, Morraye, Mde A, Reinach PS, Rocha EM. Is dry eye an environmental disease? Arq Bras Oftalmol. 2014;77(3):193-200.

6. Levy JI, Clougherty JE, Baxter LK, Houseman EA, Paciorek CJ; HEI Health Review Committee. Evaluating heterogeneity in indoor and outdoor air pollution using land-use regression and constrained factor analysis. Res Rep Health Eff Inst. 2010;(152):5-80.

7. Abusharha AA, Pearce EI, Fagehi R. Effect of ambient temperature on the human tear film. Eye Contact Lens. 2016;42(5):308-312.

8. Abusharha AA, Pearce EI. The effect of low humidity on the human tear film. Cornea. 2012;35(1):27.

9. Novaes P, do Nascimento Saldiva PH, Kara-José N, et al. Ambient levels of air pollution induce goblet-cell hyperplasia in human conjunctival epithelium. Environ Health Perspect. 2007;115(12):1753-1756.

10. Calonge M, Pinto-Fraga J, González-García MJ, et al. Effects of the external environment on dry eye disease. Int Ophthalmol Clin. 2017;57(2):23-40.

11. Azuma K, Ikeda K, Kagi N, Yanagi U, Osawa H. Prevalence and risk factors associated with nonspecific building-related symptoms in office employees in Japan: relationships between work environment, Indoor Air Quality, and occupational stress. Indoor Air. 2015;25(5):499-511.

12. Torricelli AA, Matsuda M, Novaes P, et al. Effects of ambient levels of traffic-derived air pollution on the ocular surface: analysis of symptoms, conjunctival goblet cell count and mucin $5 \mathrm{AC}$ gene expression. Environ Res. 2014;131:59-63.

13. Maruyama K, Yokoi N, Takamata A, Kinoshita S. Effect of environmental conditions on tear dynamics in soft contact lens wearers. Invest Ophthalmol Vis Sci. 2004;45(8):2563-2568.

14. Willmann G, Schatz A, Fischer MD, et al. Exposure to high altitude alters tear film osmolarity and breakup time. High Alt Med Biol. 2014;15(2):203-207. 
15. Cho P, Yap M. Schirmer test. I. A review. Optom Vis Sci. 1993;70(2): $152-156$.

16. Tomlinson A, Blades KJ, Pearce EI. What does the phenol red thread test actually measure? Optom Vis Sci. 2001;78(3):142-146.

17. Masmali A, Alrabiah S, Alharbi A, El-Hiti GA, Almubrad T. Investigation of tear osmolarity using the TearLab Osmolarity System in normal adults in Saudi Arabia. Eye Contact Lens. 2014;40(2):74-78.

18. Rickham P. Human experimentation. Code of Ethics of the World Medical Association. Declaration of Helsinki. Br Med J. 1964;2(5402):177.

19. Messmer EM, Bulgen M, Kampik A. Hyperosmolarity of the tear film in dry eye syndrome. Dev Ophthalmol. 2010;45:129-138.

20. Walt J, Rowe M, Stern K. Evaluating the functional impact of dry eye: the Ocular Surface Disease Index. Drug Inf J. 1997;31:1436.

21. Dougherty BE, Nichols JJ, Nichols KK. Rasch analysis of the ocular surface disease index (OSDI). Invest Ophthalmol Vis Sci. 2011;52(12):8630-8635.

22. Özcura F, Aydin S, Helvaci MR. Ocular surface disease index for the diagnosis of dry eye syndrome. Ocul Immunol Inflamm. 2007;15(5):389-393.

23. Sullivan B, Donsky E. Systems and methods for calibrating osmolarity measuring devices. 2007.

24. McCann LC. New developments in the diagnosis and management of dry eye disease [PhD thesis]: Glasgow Caledonian University; 2009;12.
25. Lemp MA, Hamill JR Jr. Factors affecting tear film breakup in normal eyes. Arch Ophthalmol. 1973;89(2):103-105.

26. Craig JP, Blades K, Patel S. Tear lipid layer structure and stability following expression of the meibomian glands. Ophthalmic Physiol Opt. 1995;15(6):569-574.

27. Wolkoff P. "Healthy" eye in office-like environments. Environ Int. 2008;34(8):1204-1214.

28. Tomlinson A, Khanal S. Assessment of tear film dynamics: quantification approach. Ocul Surf. 2005;3(2):81-95.

29. Sakamoto R, Bennett ES, Henry VA, et al. The phenol red thread tear test: a cross-cultural study. Invest Ophthalmol Vis Sci. 1993;34(13): 3510-3514.

30. Borchman D, Foulks GN, Yappert MC, Mathews J, Leake K, Bell J. Factors affecting evaporation rates of tear film components measured in vitro. Eye Contact Lens. 2009;35(1):32-37.

31. Patel S, Henderson R, Bradley L, Galloway B, Hunter L. Effect of visual display unit use on blink rate and tear stability. Optom Vis Sci. 1991;68(11):888-892.

32. Wolkoff P, Nøjgaard JK, Troiano P, Piccoli B. Eye complaints in the office environment: precorneal tear film integrity influenced by eye blinking efficiency. Occup Environ Med. 2005;62(1):4-12.
Clinical Optometry

\section{Publish your work in this journal}

Clinical Optometry is an international, peer-reviewed, open access journal publishing original research, basic science, clinical and epidemiological studies, reviews and evaluations on clinical optometry. All aspects of patient care are addressed within the journal as well as the practice of optometry including economic and business analyses. Basic and clinical

Submit your manuscript here: https://www.dovepress.com/clinical-optometry-journal

\section{Dovepress}

research papers are published that cover all aspects of optics, refraction and its application to the theory and practice of optometry. The manuscript management system is completely online and includes a very quick and fair peer-review system, which is all easy to use. Visit http://www.dovepress. com/testimonials.php to read real quotes from published authors. 